\title{
Legal Protection of Patients in Getting Health Services in Government Hospitals
}

\author{
Andri Anugerah Kusuma ${ }^{1}$, Suparno ${ }^{2}$ \\ University of Borobudur, Jl. Pemuda, RT.1/RW.3, Rawamangun, Kec. Pulo Gadung, DKI \\ Jakarta 13220 , Indonesia ${ }^{1,2}$ \\ \{Andri_anugerah@yahoo.com ${ }^{1}$, suparno@borobudur.ac.id² ${ }^{2}$,
}

\begin{abstract}
This paper aims to determine the legal protection for patients in obtaining health services from government hospitals in Indonesia. In this case, the patient is entitled to get the best health care from paramedics following predetermined standards. The research method used in this paper is the normative juridical method which when it is concluded that the Responsibility of the Hospital is the aspects of civil law, administrative law and criminal law, the legal protection of patients here certainly protects all patients to get the best service so that from the legal side of the patient find comfort in accepting their right to Health. By law, government hospitals are equal before the law to provide the best health services. Of course, it must provide all the prerequisites and conditions stipulated in hospital services in Indonesia.
\end{abstract}

Keywords: legal protection; patients; health service, government hospital

\section{Introduction}

Health care is a service that occurs because of the demand for public services that experience health complaints. A country must provide health insurance to citizens and the best form of health services so that its citizens have the power of immunity so that the state can carry out its development on the Health of its citizens. Currently, the quality of health services is the main focus of the community. Awareness and concern for quality are increasing. Things related to the current rate include the belief that quality must be a luxury, luxurious, and expensive item. Quality is also considered something abstract, so it can't be measured. Quality improvement efforts require a fairly costly cost (Machmud, 2008).

Patient safety has not been a culture that hospitals in Indonesia should consider. The paradigm shift in healthcare institutions currently switching to patient-centred care has not been implemented properly. Law No. 36 of 2009 on Health has clearly stated that hospitals today must put patient safety above other interests. So, he said, hospitals should be obliged to implement a culture of patient safety. There is no longer a reason for every Hospital to enforce patient safety culture because it is the material loss of acquired and a threat to patient life loss.

Legal protection is the most important thing in the management of the state of law because legal security is the right of every citizen and the state's obligation as the organizer of protection. As contained in article 3 of Law No. 29 of 2004 concerning medical practice mentions: (a) protecting patients; (2) maintain and improve the quality of medical services 
provided by doctors and dentists, and (c) provide legal certainty to the community of doctors, and dentists.

Based on these provisions, there is a conclusion as follows that any implementation of medical practice that is the core of various activities in the performance of different health efforts must be carried out by doctors and dentists who have high ethics and morals, expertise and authority that continuously must be improved through education and continuous training following the development and knowledge and technology in the field of medicine.

Indonesia as a legal state is obliged to protect its citizens, as outlined in the preamble to the 1945 Constitution, the second paragraph stating "An independent, united, sovereign, just and prosperous Indonesia" if the sentence is related to the purpose of the state contained in the fourth paragraph which states '... protecting the entire Nation of Indonesia and all Indonesian bloodshed to realize the general welfare, educate the nation's life and participate in carrying out world engagement based on independence, lasting peace and social justice (Azhary, 2015).

If we go further, will there be legal protection for patients in government hospitals? There needs to be the protection of hospital patients because it is the patient's right to shelter from the problem of malpractice. The patient is entitled to the best health care under the disease he complained about, which is part of patients' human rights. The purpose of this paper is to know about legal protection for patients when getting health services at government hospitals. National health insurance may have been given to BPJS Health. While the legal protection aspect of the patient who has not seen well who handled it. Therefore, the author had the opportunity to write this paper.

\section{Methods}

This paper uses an empirical juridical approach, namely, research studies the prevailing legal provisions and reality in society. This method serves to examine how the law works in the community.

\section{Results and Discussion}

\subsection{Patient Legal Protection}

The relationship between patients and doctors is the relationship between the legal subject as a patient receiving health care services and the doctor as the subject of health care providers (Asram AT Jadda, 2017). Between the patient and the doctor, there are rules or rules of civil law and meet the relationship regarding the arrangement of the parties' rights and obligations. Medical practice is not a job that anyone can do. Still, it should only be done by certain groups of medical professionals who have competencies that meet certain standards, are authorized by authorized institutions in that field and work following the standards and professionalism set by professional organizations.

Theoretically-conceptually, between the professional community and the general public, there is a contract (referring to the doctrine of social-contract), which gives the professional organization the right to self-regulating (professional autonomy) with the obligation to assure that professionals who practice are only competent and who carry out their professional practices under standards. 
Professionalism is a responsible attitude, in the sense of attitudes and behaviours accountable to the community, both professional society and the wider community (including clients). Some of the characteristics of professionalism are the characteristics of the profession itself, such as competence and authority that is always "under the place and time", ethical attitudes following the ethics of the domain, working following the standards set by profession, and specifically for the health profession coupled with an altruist attitude (willing to sacrifice). The description of these characteristics should be lived and practised for professionalism to be realized.

Law No. 29 of 2004 on Medical Practice was enacted to regulate medical practice to provide protection to patients, maintain and improve the quality of medical services, and provide legal certainty to the public, doctors, and dentists. The Law on Medical Practice will not be applied perfectly if the rules of implementation have not been made.

Experts in the field of Health carry out the profession based on a job that contains risks. If the person has performed his duties correctly according to professional benchmarks (professional standards), the concerned must get legal protection (Herkutanto, 1987: 35). The legal Responsibility of doctors and health workers is based on the professional code of ethics. The development of the professional code of ethics to be adhered to and implemented by its supporters contains 3 (three) objectives, namely: first, a professional code of ethics facilitates efficient decision making; second, individually the experienced leaders often need direction to direct their professional behaviour; and third, professional ethics creates a pattern of behaviour that is expected by its customers professionally.

\subsection{Government Hospital Health Services}

Law No. 44 of 2009 on Hospitals, governing hospitals' Responsibility, Article 46 states: Hospitals are legally responsible for all losses incurred by health workers in hospitals. Article 45 paragraph: (1) Hospitals are not legally responsible if patients and their families refuse or discontinue treatment that could result in the death of a patient after a comprehensive medical explanation, and (2) the Hospital cannot be prosecuted for carrying out its duties to save human lives.

Article 45 paragraph (1): The patient has the right to refuse or discontinue treatment. Patients who refuse treatment for financial reasons should be explained that the patient is entitled to a guarantee from the Government. There are 4 (four) sections related to the Responsibility of the Hospital as a medical service, namely: (1) responsibility to personnel: (2) professional responsibility for quality; (3) responsibility for facilities/equipment: (4) responsibility for building safety and maintenance (Sandiata, 2013).

Civil law distinguishes hospitals' category always defendants (corporations), namely government hospitals and private hospitals concerning government hospitals, government hospitals' management c.p. Lex Administratum office, Vol.I/No.2/Apr-Jun/2013 health minister of Health can be prosecuted according to Article 1365 of the civil code Because employees who work in government hospitals become civil servants. The state as a legal entity can be required to pay compensation for civil servants who carry out their duties to the detriment of other parties. At the same time, the management of private hospitals applied Article 1365 and Article 1367 civil code because private hospitals as legal entities have their wealth and can act in law and can be prosecuted and humans (Tutik \& Febriana, 2010).

The form of compensation is intended to improve the situation and replace losses, mostly in the form of a large amount of money. The substitute for such losses must be assessed according to both parties' ability and position and must also be adjusted to the circumstances. 
The most recent provision generally applies in indemnification issued from an unlawful act against a person.

Law No. 44 of 2009 concerning Hospitals governing patient safety. Article 43 paragraph: (1) Hospitals shall apply patient safety standards, (2) Patient safety standards as referred to in paragraph (1) shall be implemented through incident reporting, analyzing, and establish problem-solving to reduce the number of unexpected events, (3) Hospitals report activities as referred to in paragraph (2) to the committee in charge of patient safety stipulated by the Minister, (4) Reporting of patient safety incidents as referred to in paragraph (2) is made anonymously and intended to correct the system to improve patient safety, and (5) Further provisions on patient safety standards as referred to in paragraph (1) and paragraph (2) shall be governed by the Ministerial Regulation.

Reviewed in terms of public science, doctors and patients' relationship shows that doctors have a dominant position. In contrast, patients only have a passive attitude of waiting without the authority to fight. This position has historically lasted for many years in which the doctor played a major role, both because of his special knowledge and skills, and because of the authority brought by him because he was a small part of society that for many years was domiciled as a party that has the control of the field in providing medical assistance based on the full trust of patients (Nurdin, 2015).

The first thing to know is that to create legal protection for patients, and the parties must understand the rights and obligations attached to them, including health care providers, to be responsible for the profession provided to the recipients of health care services (Hasan \& Putra, 2018). The law gives protection of the right to obtain health services for the community. That is part of the implementation of human rights protection that has been mandated in the Constitution of the Republic of Indonesia year 1945 (Supriyanto, 2020).

The same rights and opportunities to obtain health services apply to everyone through health facilities such as government hospitals to provide safe, quality and affordable health services. The public can utilize health resources offered by the government and local governments. The fulfilment of the right to obtain proper health services through health facilities in government hospitals is guaranteed and implemented by the government and local governments organized by the Technical Implementation Unit of agencies in charge of Health, certain agencies, or regional technical institutions with management by the Public Service Agency or Regional Public Service Agency to ensure the availability of all forms of quality, safe, efficient, and affordable health efforts.

\section{Conclusion}

Legal protection of the right to obtain health services for the public is part of the implementation of human rights protection as mandated by the Constitution of the Republic of Indonesia of 1945. The community has the same rights and opportunities to obtain safe, quality and affordable health services. It is entitled to independently and responsibly determines the health services necessary for itself and is entitled to utilize health resources provided by the government and local governments. The fulfilment of the right to obtain proper health services through health facilities in government hospitals is guaranteed and implemented by the government and local governments organized by the Technical Implementation Unit of agencies in charge of Health, certain agencies, or regional technical institutions with management by the Public Service Agency or Regional Public Service 
Agency to ensure the availability of all forms of quality, safe, efficient, and affordable health efforts.

Government hospitals are obliged to provide health services, especially in emergencies, to save a patient's life and prevent disability and are prohibited from rejecting patients and requesting a down payment. Government hospitals are obliged to conduct health care efforts, both promotive, preventive, curative and rehabilitative. This paper's advice is that the implementation requires effective supervision by the government and/or local governments through cooperation with non-government agencies and the public to monitor, evaluate, and report on the fulfilment of community rights and constraints in obtaining health services.

\section{References}

[1] Hasan, Sabri, and Aditya Halim Perdana Kusuma Putra. 2018. "Loyalitas Pasien Rumah Sakit Pemerintah: Ditinjau Dari Perspektif.” Jurnal Manajemen Indonesia 18(3): 184-96.

[2] Sibarani, Sabungan. 2017. “Aspek Perlindungan Hukum Pasien Korban Malpraktik Dilihat Dari Sudut Pandang Hukum di Indonesia." Justitia et Pax 33(1): 1-22.

[3] Azhary, H Muhammad Tahir. 2015. Beberapa Aspek Hukum Tata Negara, Hukum Pidana Dan Hukum Islam. Prenada Media.

[4] Tutik, Titik Triwulan, and Shita Febriana. 2010. Perlindungan Hukum Bagi Pasien. Prestasi Pustaka Publisher.

[5] Asram AT Jadda. 2017. "Perlindungan Hukum Terhadap Pasien Sebagai Konsumen Jasa Pelayanan Kesehatan." Madani Legal Review 1(1): 1-28.

[6] Nurdin, M. 2015. "Perlindungan Hukum Terhadap Pasien Atas Korban Malpraktek Kedokteran.” Jurnal Hukum Samudra Keadilan 10(1): 92-109. https://media.neliti.com/media/publications/240395-perlindungan-hukum-terhadappasien-atas-97f6abae.pdf.

[7] Sandiata, Oleh Stefany B. 2013. "PERLINDUNGAN HUKUM HAK MENDAPATKAN PELAYANAN KESEHATAN Di RUMAH SAKIT PEMERINTAH." Lex Administratum 1(2): 187-94.

[8] Supriyanto, Eko Eddya. 2020. Eksistensi Nilai-Nilai Pancasila Dalam Kebijakan Ekonomi Indonesia. 1st ed. Malang: Literasi Nusantara. 